\title{
Studies on the life cycle and reproduction of the parasitic amphipod Hyperia galba in the North Sea
}

\author{
Birgit Dittrich* \\ Lehrstuhl für Spezielle Zoologie und Parasitologie, \\ Ruhr-Universität Bochum; D-4630 Bochum 1 \\ and \\ Biologische Anstalt Helgoland (Meeresstation); D-2192 Helgoland, \\ Federal Republic of Germany
}

\begin{abstract}
The structure of a Hyperia galba population, and its seasonal fluctuations were studied in the waters of the German Bight around the island of Helgoland over a period of two years (1984 and 1985). A distinct seasonal periodicity in the distribution pattern of this amphipod was recorded. During summer, when its hosts - the scyphomedusae Aurelia aurita, Chrysaora hysoscella, Rhizostoma pulmo, Cyanea capillata and Cyanea lamarckii - occur in large numbers, supplying shelter and food, a population explosion of $H$. galba can be observed. It is caused primarily by the relatively high fecundity of $H$. galba which greatly exceeds that of other amphipods: a maximum of 456 eggs was observed. The postembryonic development is completed in the medusae infested; only then are the young able to swim and search for a new host. The smallest fréely-swimming hyperians obtained from plankton samples were $2.6 \mathrm{~mm}$ in body size. The size classes observed as well as moult increment and moulting frequencies in relation to different temperatures suggest that two generations are developed per year: a rapidly growing generation in summer and a slower growing generation in winter that shifts to a benthic mode of life and hibernation. For short periods, adult hyperians may become attached to zooplankters other than scyphomedusae. However, when releasing the progeny, they are dependent on the presence of these coelenterates. Apparently, a host specificity does not exist. During daytime, the hyperians seem to avoid a host change; only $0.2 \%$ of all the individuals sampled in the plankton during the day were not associated with medusae. The heavy infestation of medusae by this crustacean leads to a weakening and a progressive breakdown of these important predators on fish larvae. $H$. galba occupies a specific position in the marine food web which is discussed in detail.
\end{abstract}

\section{INTRODUCTION}

The amphipod suborder Hyperiidea - besides the copepods and euphausiaceans, the ecologically most important group of planktonic crustaceans - comprises species which are in many ways associated with larger pelagic organisms; in most of the cases these associations are species-specific. Harbison et al. (1977) found intimate relationships within 30 hyperiid genera, and the actual percentage of parasitic or commensal hyperiids is presumably much higher. Hyperia galba (Montagu) is a widespread parasite of the large scyphomedusae Aurelia aurita, Chrysaora hysoscella, Rhizostoma pulmo, Cyanea

\footnotetext{
- Private address: Isenbergstr. 58, D-4300 Essen 1
} 
capillata and Cyanea lamarckii: It appears to be a cosmopolitan and is distributed especially in shallow waters such as in the North Sea and the Baltic Sea (cf. Lauckner, 1980).

Hyperia galba, settling on scyphozoans during its pelagic stage of life, selects a remarkable habitat and thus occupies an ecological niche which - at least in European seas - is not utilized by any other species.

One of the earliest descriptions of its mode of life was given by Gould (1841): ". . this curious animal is found in the pouches of large Medusae ...". He stated further: "Whether they make this their home or become entrapped there or not, it would be difficult to determine. They seem however to be quite at their ease in their situation." Edward (1866) who still separated Lestrigonus kinahani (today: $\delta$ o of Hyperia galba!) and $H$. galba (his descriptions concerned only $q q$ of this species) discovered that the individuals of both species appear first about June and disappear at the end of September.

The first studies on the life cycle of Hyperia were made by Metz (1967) in the Isefjord area (Denmark). He found a distinct temperature dependence in the development of the population and the infestation of the medusae.

In the studies carried out in the German Bight on planktonic organisms, hyperiids have up to now been neglected, although Sokolowsky (1900) noted that $H$. galba is often observed in the waters around Helgoland. Thus, since Hollowday's (1947) conclusion that "... apparently very little is known concerning the life history and the reproductive periods of $H$. galba ...", not much has changed. So far, detailed studies on the mode of life, population dynamics, life cycle and reproduction of this parasitic species occurring in masses during summer and autumn do not exist.

\section{MATERIAL AND METHODS}

\section{Sample taking}

In order to ascertain potential hosts the coelenterates were caught in the following way: (a) medusae were picked up individually by means of a hand net from aboard a boat; (b) 470 plankton samples were taken over two years by means of a CALCOFI-net (mesh width $500 \mu \mathrm{m}$ ) from different depths (maximally $50 \mathrm{~m}$ ); (c) bottom samples were taken around Helgoland and in the area of the Weser-Elbe-estuary to a depth of maximally $50 \mathrm{~m}_{i}$ (d) scratch samples were taken from the richly covered piers and boulders around Helgoland; (e) samples were picked up specifically from the sea bottom in the course of several divings.

The medusae caught were packed individually in plastic bags so that the infestation of the scyphozoans could be investigated in the laboratory. A distinction was made between infestation rate and individual infestation: prevalence of infestation characterizes the percentage of medusae infested with Hyperia; the individual infestation denotes the average number of parasites per individual host.

The hyperians were fixed in $4 \%$-glutaraldehyd-seawater. As $\$$ \%ov generally release the eggs from the marsupium even when anaesthetized, they were preserved individually for a quantitative analysis of the individual brood size. Marsupia with juveniles were disregarded, because some larvae could have already been released. 
To measure the diameter of the umbrella, the medusae were put upside down into a shallow glass dish. The total body length of Hyperia galba was determined by means of an ocular micrometer, measuring the distance between the anterior edge of the head (without antennae) and the telson tip (without uropods) when the animal was stretched out. Sex discrimination was possible in animals at $\geq 3.0 \mathrm{~mm}$ size.

Egg diameter was measured only among uncleaved eggs. The duration of embryonic development was determined starting from the 4-cell-stage, because rinsing of marsupia yielded only few uncleaved eggs. The embryos were cultivated in shallow glass dishes at different, constant temperatures. The temperated, filtrated seawater was changed daily, and decayed or mouldering eggs were removed.

For the determination of moulting frequencies, the animals were maintained at different, constant temperatures; they were each measured one day after moulting. The moult increment is the rate of increase in length related to the body length prior to moulting.

Geography and hydrography of the area of investigation

The area of investigation extends over the whole of the German Bight including the waters around Helgoland and the Weser-Elbe-estuary.

The North Sea is influenced by mainly western winds, which cause heavy rainfall without extreme temperatures. The Gulf Stream effects relatively high water temperatures in relation to the latitude occupied. In winter, water temperatures are always above freezing point; in very cold winters, drift ice occurs near the southeastern coasts.

Measurement of water temperature (Fig. 1a) and salinity (Fig. 1b) of the surface water was carried out daily between 08.00 and $11.00 \mathrm{~h}$ at a depth of $1 \mathrm{~m}$ near the cable buoys of the Helgoland roads.

\section{RESULTS}

\section{Population structure and dynamics}

The seasonal variation of the population structure was studied by collecting hyperians regularly from plankton samples and from freshly caught medusae. The quantitative analysis is based on approximately 18000 individuals taken during the day from plankton samples and medusae catches. $99.8 \%$ of all hyperians were found on scyphomedusae (Table 1). This clearly reflects the intimate association between host and parasite. Only 44 hyperians were found not associated with medusae in 19 out of 470 plankton samples taken $_{i}$ generally, mainly single individuals and maximally 4 animals were found within one haul.

The intimate association between parasite and host becomes evident in the seasonal periodicity of the abundances of hyperians as well as of scyphozoans. During the winter months, scyphomedusae generally do not occur in the North Sea; Hyperia is also absent at this time. After strobilation in winter and early spring, numerous ephyrae, but no hyperians, appear in the plankton. The first small medusae of Aurelia aurita (medium diameter of the umbrella: ca 4-8 cm) normally appear in May or June (Fig. 2); they are occasionally inhabited already by hyperians which are, in most cases, juveniles or subadults of 3-6 mm body size (Fig. 3). As long as the gonads of the growing medusae are not yet mature, their infestation rate increases only slightly (Fig. 4); on the average, a 

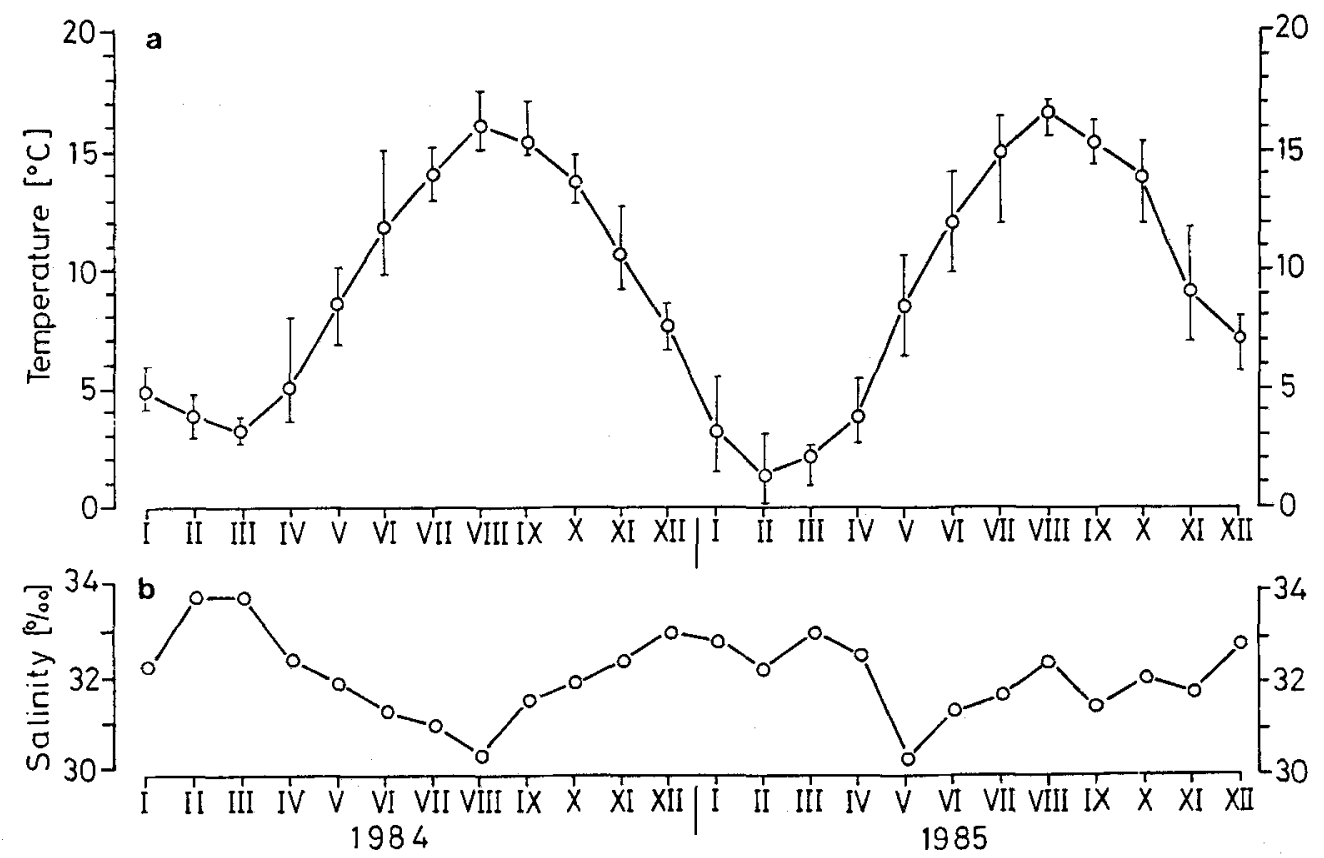

Fig. 1. Temperature (mean values and maximal deviations) (Fig. 1a) and salinity (mean values) (Fig. 1b) of the surface waters at Helgoland. Unpublished data from Mangelsdorf \& Treutner, BAH

Table 1. Distribution of hosts associated with Hyperia galba. Samples taken in the German Bight during daytime in the years 1984-1986

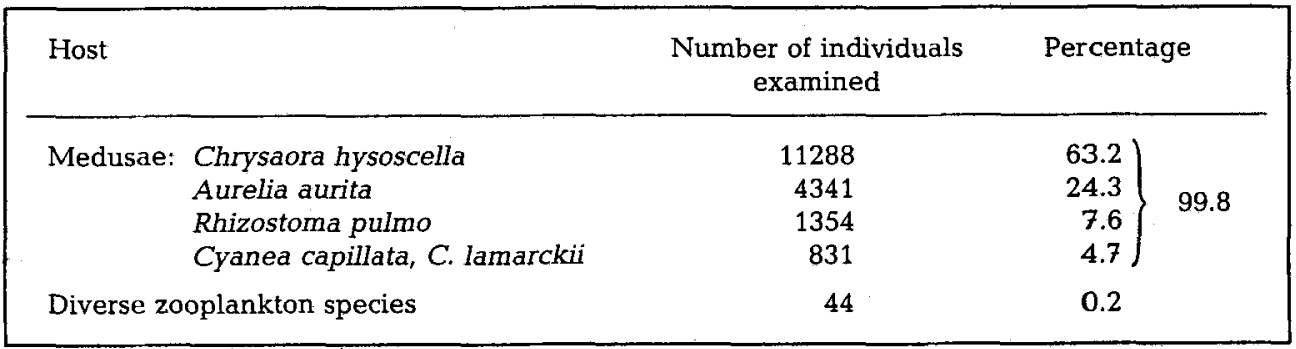

medusa is infested by less than 0.5 hyperians (Fig. 5). The close relationship existing between the developmental cycles of both species becomes evident by the reproductive activity of the amphipod which begins approximately 3 weeks after the maturation of the gonads in the jellyfish. At the end of July, most of the medusae show mature gonads and many of them bear planula-larvae. The medium diameter of the umbrella is almost the same in June and July; during this time, many individuals show a reduction or even complete loss of gastric filaments, tentacles and oral tentacles. A characteristic feature is the transition from the typical umbrella-like shape of the medusae to a more or less spherical form of the jelly mass which hardly shows any morphological differentiations. 


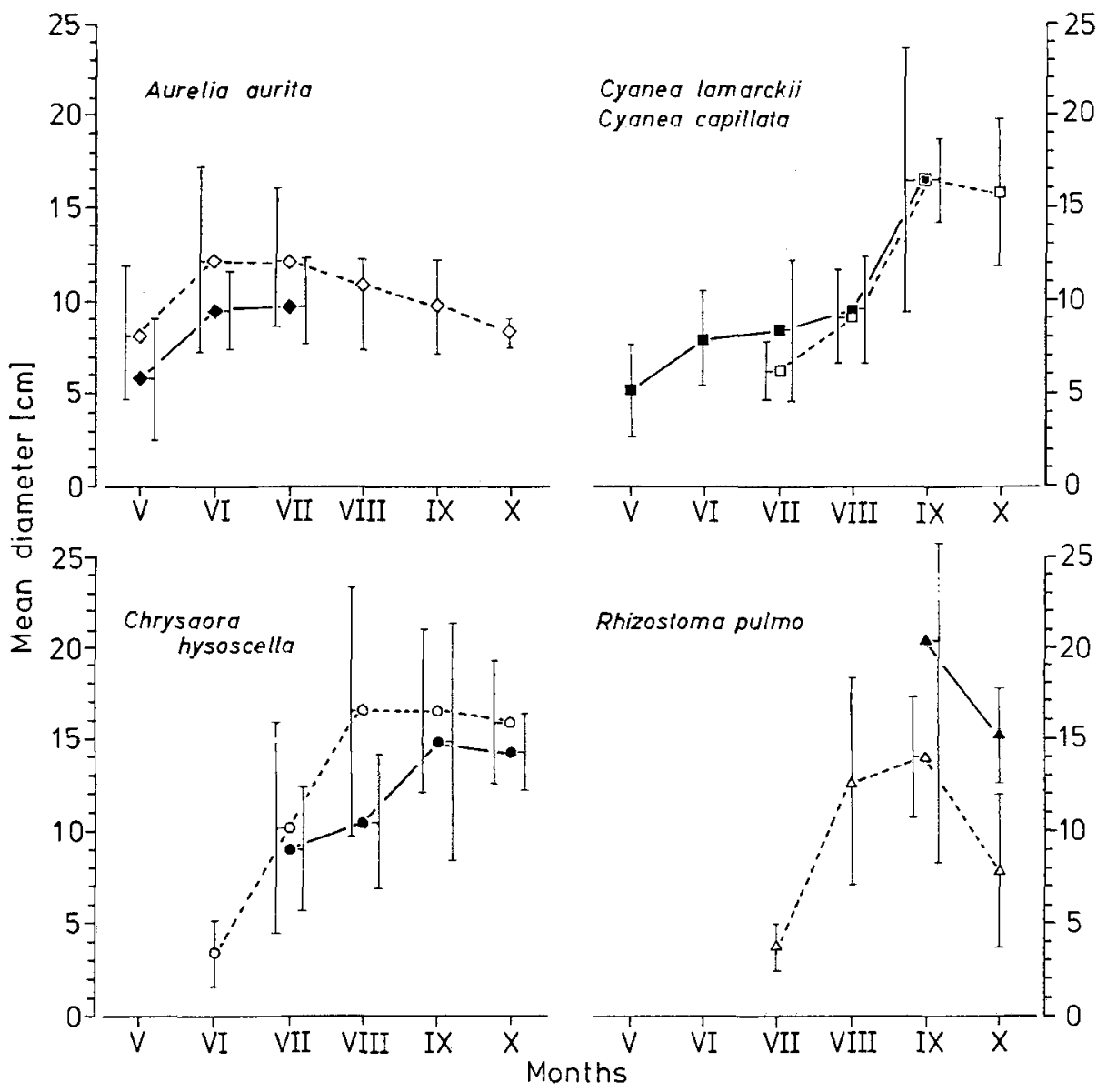

Fig. 2. Seasonal size development of the umbrella (mean diameter \pm standard deviation) of scyphozoa examined in the waters of Helgoland during the course of the observation period. Open symbols $=1984 ;$ closed symbols $=1985$

During this period, the prevalence of infestation of the medusae increases rapidly. At the beginning of October, at the latest, almost all medusae are infested; hyperians stay preferably on the oral tentacles where they feed on trapped zooplankton or on the gonads of the host. A corresponding development can be observed within the other species of scyphomedusae which appear somewhat later as free-floating organisms.

During autumn, the infestation rate attains an extent that so far has not been described; up to 62 hyperians were found on Aurelia aurita, 93 on Cyanea capillata, 153 on Rhizostoma pulmo and 486 on Chrysaora hysoscella. Usually, at the end of October or in early November, the medusae are extinguished. At the same time, Hyperia galba disappears too. Neither of the two enter the pelagic environment again until the next spring. 


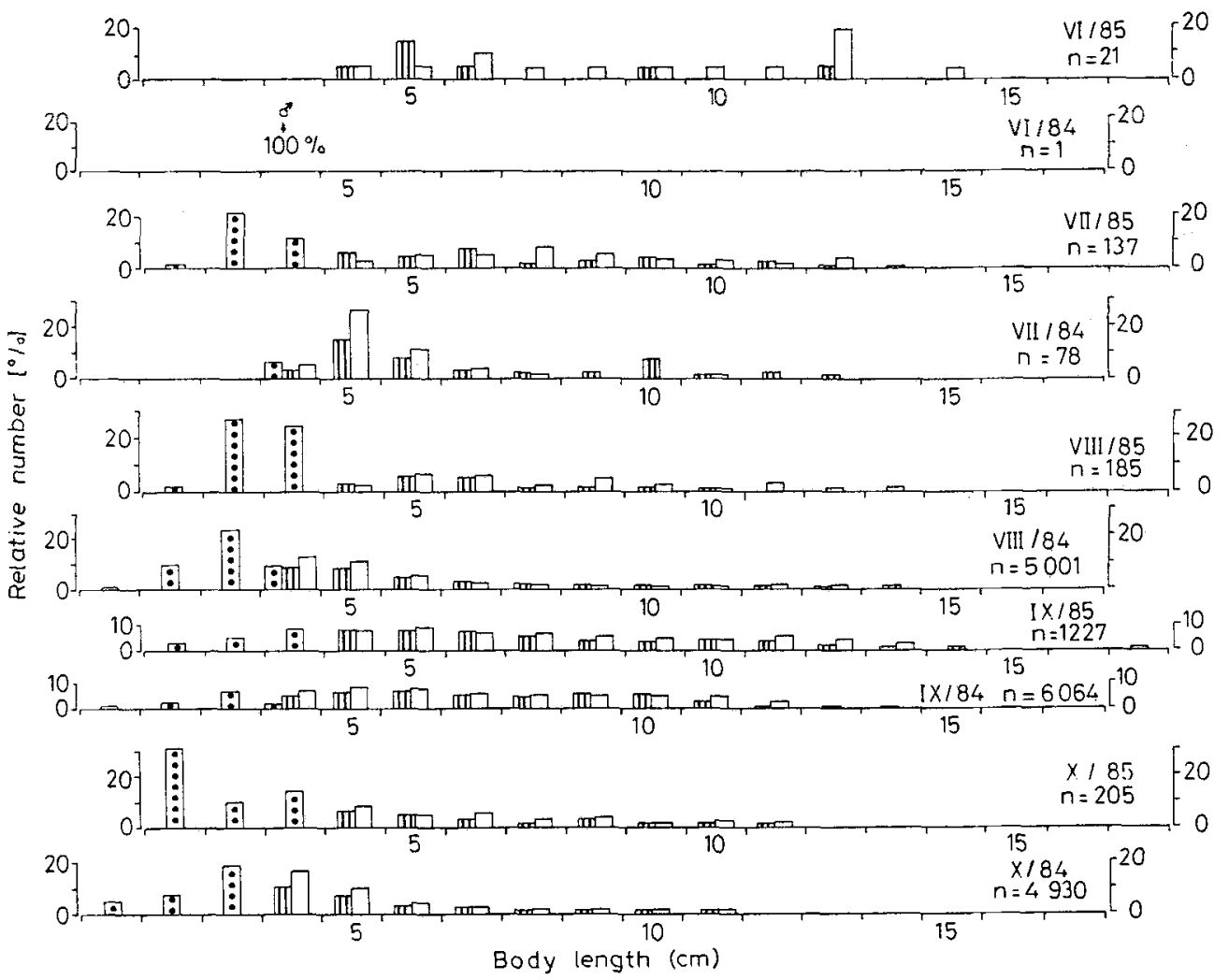

Fig. 3. Size frequency of Hyperia galba in 1984 and 1985. Striped bars: $\delta \delta^{*}$; blank bars: $q q$; dotted bars: sexually undifferentiated juveniles

\section{Sex ratio}

The sex ratio of Hyperia galba shows a slight predominance of females. The ratio $\delta \delta: q 9$ amounts (during months with catches of $>21$ hyperians) to between $1: 1.1$ and 1:1.7 (Table 2); the mean value for the whole period of investigation was $1: 1.3$.

\section{Host preference}

The intimate association between Hyperia and scyphozoans gives rise to the question as to whether or not certain coelenterate species are preferred as hosts. In order to examine this open question under laboratory conditions, scyphozoans and hyperians were kept in a large aquarium, i. e. one medusa of Aurelia aurita, Chrysaora hysoscella, Rhizostoma pulmo, Cyanea lamarckii and Cyanea capillata (diameter of the umbrella: $8-10 \mathrm{~cm}$ ) together with only one Hyperia individual. Generally, the Hyperia swims around undirected and after $10 \mathrm{~min}$ at the latest settles on a medusa. The choice of the medusa probably occurs by chance. A host change which may occur afterwards does not indicate any host preference. Possibly, the hyperians regularly change their host in the natural environment too; this assumption is supported by the fact that the size classes of 


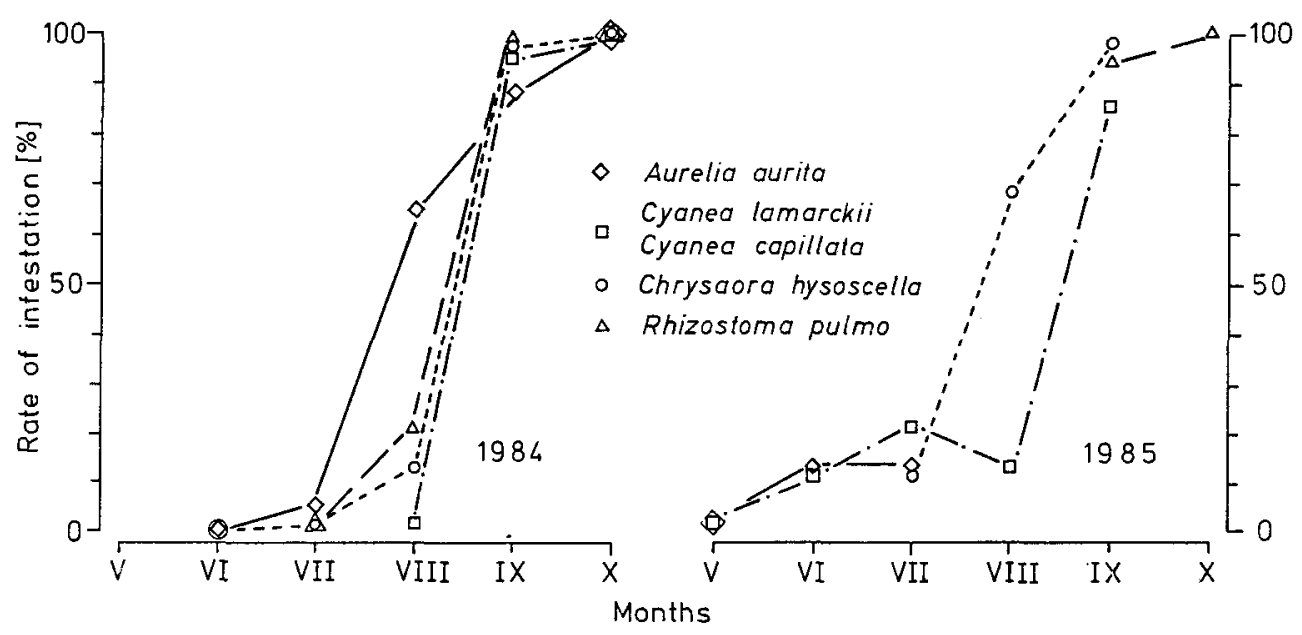

Fig. 4. Infestation rate of scyphomedusae during 1984 and 1985

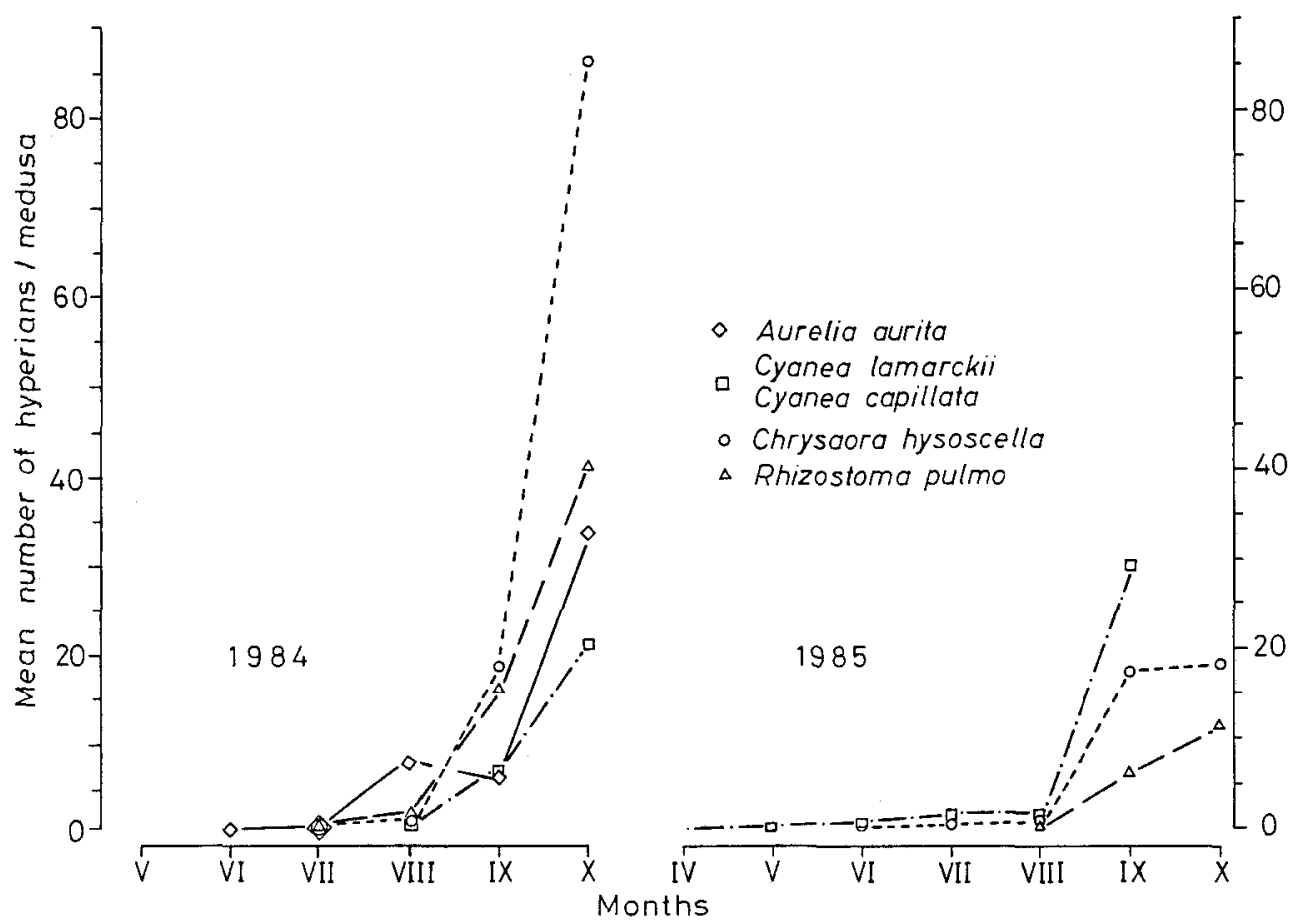

Fig. 5. Mean individual infestation of scyphomedusae

the hyperians found on a single medusa are approximately equal to the corresponding monthly size classes of the Hyperia-population (Fig. 3). Most of the hyperians were found on those scyphomedusae exhibiting mature gonads; in fact, the infestation rate was highest within these scyphozoans (Figs 4 and 5). 
Table 2. Seasonal abundances of $\delta \sigma^{*}$ and $q \uparrow$ hyperians ( $\geq 3.0 \mathrm{~mm}$ body length) and sex ratio. ${ }^{*}$ less than 22 Hyperia galba caught

\begin{tabular}{|c|c|c|c|c|}
\hline \multirow[t]{2}{*}{ Year } & \multirow[t]{2}{*}{ Month } & \multicolumn{2}{|c|}{ Number of } & \multirow[t]{2}{*}{$\delta \sigma^{*}: 99$} \\
\hline & & 80 & 99 & \\
\hline \multirow{8}{*}{1984} & May & - & - & - \\
\hline & Jun. & - & - & $-\quad *$ \\
\hline & Jul. & 35 & 38 & $1: 1.1$ \\
\hline & Aug. & 1334 & 1684 & $1: 1.3$ \\
\hline & Sep. & 2365 & 3027 & $1: 1.3$ \\
\hline & Oct. & 1424 & 2016 & $1: 1.4$ \\
\hline & Nov. & 1 & 1 & $1: 1.0^{*}$ \\
\hline & Dec. & 2 & 1 & $2: 1.0^{*}$ \\
\hline \multirow{12}{*}{1985} & Jan. & - & - & - \\
\hline & Feb. & - & - & - \\
\hline & Mar. & - & - & - \\
\hline & Apr. & - & - & - \\
\hline & May & - & 2 & $0: 2.0^{*}$ \\
\hline & Jun. & 7 & 14 & $1: 2.0^{*}$ \\
\hline & Jul. & 41 & 51 & $1: 1.2$ \\
\hline & Aug. & 32 & 53 & $1: 1.7$ \\
\hline & Sep. & 479 & 570 & $1: 1.2$ \\
\hline & Oct. & 40 & 57 & $1: 1.4$ \\
\hline & Nov. & - & 1 & $0: 1.0^{*}$ \\
\hline & Dec. & - & - & - \\
\hline
\end{tabular}

\section{Reproduction}

The reproduction of Hyperia in the North Sea is restricted to the period between August and October. From November to June, solitary hyperians were occasionally observed, but these were never $q$ \%ov.

The fecundity is relatively high and exceeds the egg production of other amphipods significantly (Cheng, 1942; Kinne, 1960; Sheader \& Chia, 1970; Steele \& Steele, 1975; Sheader, 1977; Anger, 1979). The maximal egg number found within the hyperians investigated around Helgoland was 456 in a female of $13.6 \mathrm{~mm}$ body length caught in October. The female showing the smallest egg number observed (61 eggs) had a body length of $7.0 \mathrm{~mm}$ it was caught in September (Table 3). The average large diameter of the ellipsoid Hyperia-eggs is $422 \pm 17 \mu \mathrm{m}$.

Table 3. Body lengths of $q q$ ov and egg numbers. $n$ : number of $q q$ ov investigated

\begin{tabular}{|lrccccc|}
\hline Month & $\mathrm{n}$ & $\begin{array}{c}\text { Number of } \\
\text { eggs (range) }\end{array}$ & $\begin{array}{c}\text { Mean } \\
\text { number } \\
\text { of eggs }\end{array}$ & $\begin{array}{c}\text { Body length } \\
\text { of } 9 \text { \% ov } \\
\text { (range) }[\mathrm{mm}]\end{array}$ & $\begin{array}{c}\text { Mean body } \\
\text { length of } \\
\text { } 9[\mathrm{~mm}]\end{array}$ & $\begin{array}{c}\text { Water } \\
\text { temperature } \\
{\left[{ }^{\circ} \mathrm{C}\right]}\end{array}$ \\
\hline Aug. & 17 & $109-450$ & $257.7 \pm 89.1$ & $9.3-13.0$ & $11.4 \pm 1.1$ & 16.5 \\
Sep. & 146 & $61-430$ & $234.1 \pm 71.5$ & $7.0-13.9$ & $11.0 \pm 1.2$ & 15.4 \\
Oct. & 84 & $65-456$ & $227.2 \pm 81.2$ & $7.4-13.6$ & $10.7 \pm 1.1$ & 13.7 \\
\hline
\end{tabular}


Table 4. Relationship between egg number and body length of Hyperia galba $q \%$. Correlation coefficients $(r)$ and regression constants $(a$ and $b$ ) for the regression lines given in Fig. $6 . n=$ number of $\$$ ov investigated

\begin{tabular}{|lrrrrrrrr}
\hline Month & $\mathrm{n}$ & \multicolumn{3}{c}{$\mathrm{y}=\mathrm{a}+\mathrm{bx}$} & \multicolumn{3}{c}{$\mathrm{y}=\mathrm{a} \times^{\mathrm{b}}$} \\
& & $\mathrm{r}$ & $\mathrm{a}$ & $\mathrm{b}$ & $\mathrm{r}$ & $\mathrm{a}$ & $\mathrm{b}$ \\
\hline Aug. & 17 & 0.769 & -443.92 & 61.74 & 0.774 & -1.208 & 2.763 \\
Sep. & 146 & 0.900 & -345.22 & 53.42 & 0.901 & -0.755 & 2.592 \\
Oct. & 84 & 0.879 & -462.00 & 64.26 & 0.866 & -2.162 & 3.177 \\
\hline
\end{tabular}

The statistical analysis of the measurements revealed that the correlation between egg number and body length of the Hyperia- $q 9$ is at a maximum when based on a linear or a power function (Table 4, Fig. 6), respectively. The relatively low correlation in August is obviously due to the small amount of females available at this time. The only slight differences observed between the regression coefficients in August, September and October (Table 4) are obviously due to the minor temperature differences ranging between 14 to $17^{\circ} \mathrm{C}$ at this time (Fig. 1a). Actually, in the course of the summer, a decrease in the average monthly egg number occurred (Table 3), which can be accounted for by the decrease in the average body length of the $\$ q$ ov from $11.4 \mathrm{~mm}$ in August to $10.7 \mathrm{~mm}$ in October. The egg number - related to the body length of the $q q$ - remains constant under the conditions given (Fig. 7). Also, the size spectra of the $\% q$ ov are fairly constant during the whole reproductive period (Fig. 8). The deviation in August may be

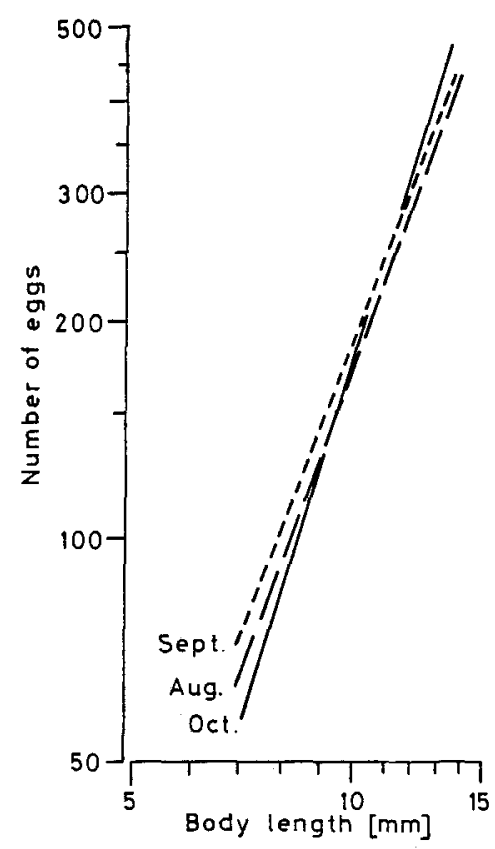

Fig. 6. Hyperia galba. Relationship between egg number and female body length. (For correlation coefficients and regression constants see Table 4) 


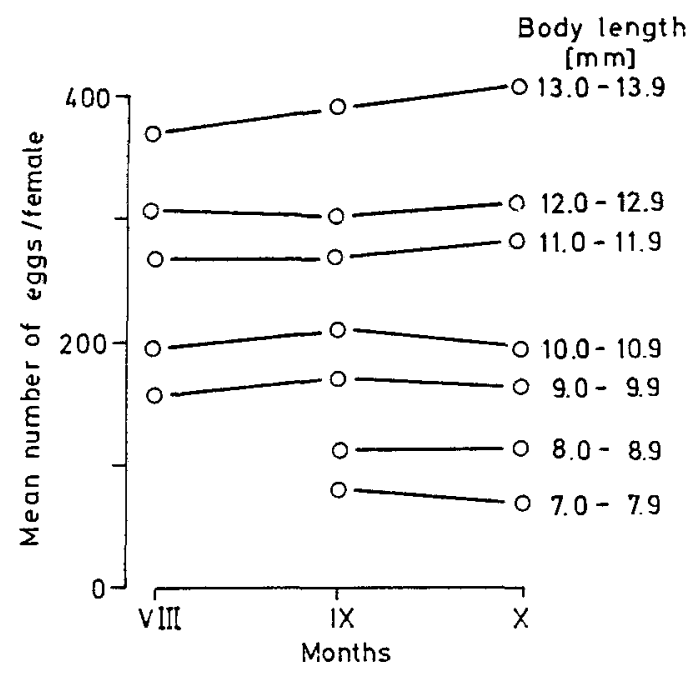

Fig. 7. Hyperia galba. Mean number of eggs in relation to female body length during the reproduction period in 1984

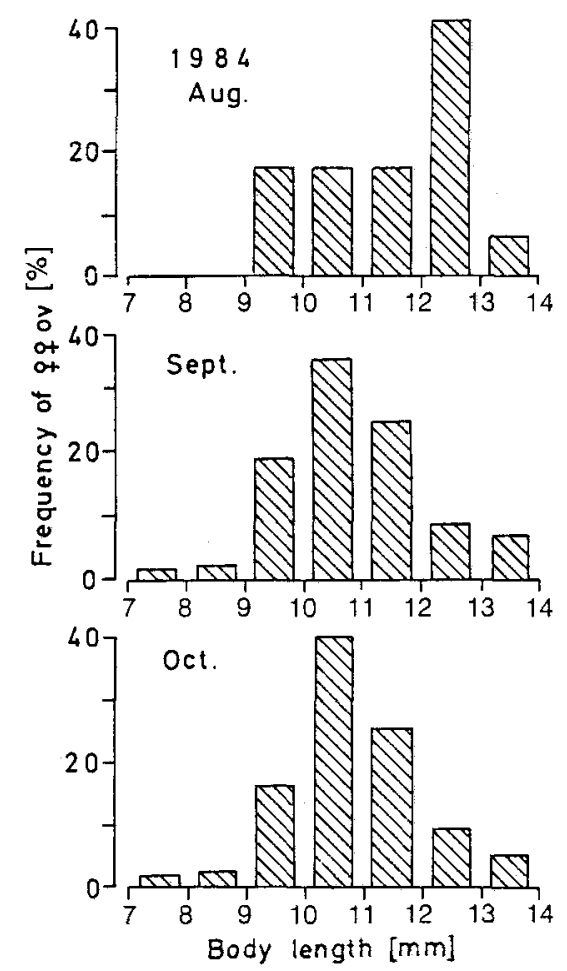

Fig. 8. Size distribution of Hyperia galba $q \varsubsetneqq$ ov (1984). Number of $q q$ ov investigated in August: 17; in September: 146 ; in October: 84 
due to the relatively small amount of $q 9$ ov available at this time. The $q q$ active first in reproduction in summer are larger than those reproducing during the following weeks. The highest portion of egg and larvae-bearing $\% q$ is found in the $12 \mathrm{~mm}$-size class in August.

The relation between egg number and body length of the $q q$ does not show great differences during the reproductive period, nor do the spectra of the individual brood sizes between August and October (Fig. 9). During these months, the group of $q 9$

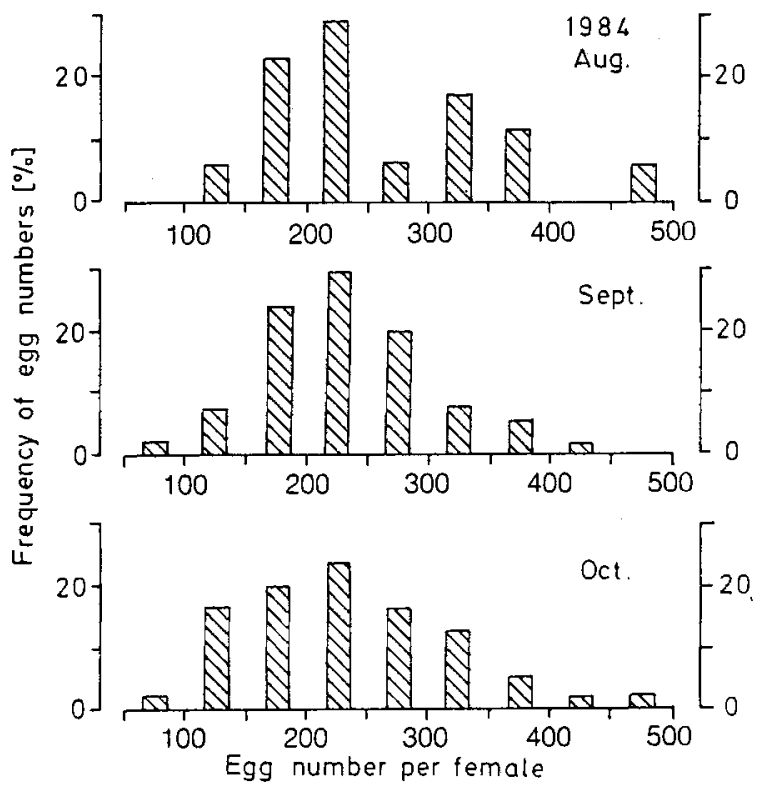

Fig. 9. Relative number of eggs per Hyperia galba $\$ 9$ (1984)

carrying 200-250 eggs in the marsupium is the largest one: a brood of this size was observed in $29.4 \%$ of the $9 \%$ ov investigated in August; in September this percentage was $30.1 \%$ and in October $23.8 \%$.

During the entire reproduction period, the percentage of $q 9$ ov remains very low (Table 5). Disregarding June 1985 with only 21 individuals caught, the percentage of $q q$ ov in all $q q$ is maximally $14.6 \%$ and the percentage within the population does not exceed $6.8 \%$.

\section{Duration of embryonic development}

The development of Hyperia-eggs was studied over the entire temperature range tested. The temperatures of $0{ }^{\circ} \mathrm{C}$ and $20^{\circ} \mathrm{C}$ turned out to be critical, since cleavage and embryogenesis were generally not completed. At $0^{\circ} \mathrm{C}$, just 5 larvae hatched out of 90 eggs; however, they did not develop further and died while still in the first larval stage. Strikingly, the eggs of this arctic-boreal species develop even at $20^{\circ} \mathrm{C}$. The mortality rate of the young hatched at this temperature is very high, and most of the individuals do not survive the larval period. Slight thermal changes at upper temperature levels have less 
Table 5. Percentage of $q q$ ov and juveniles examined. $*$ samples comprising less than 22 hyperians investigated. For number of animals investigated see Fig. 3

\begin{tabular}{|c|c|c|c|c|}
\hline Year & Month & $\begin{array}{l}\text { Percentage } \\
\text { all females } \\
(\geq 3.0 \mathrm{~mm})\end{array}$ & $\begin{array}{l}\text { n relation to } \\
\text { all } \\
\text { individuals }\end{array}$ & $\begin{array}{c}\text { Percentage of } \\
\text { juveniles }(<3 \mathrm{~mm}) \\
\text { in the population }\end{array}$ \\
\hline \multirow{8}{*}{1984} & May & & & \\
\hline & Jun. & & & $100.0^{*}$ \\
\hline & Jul. & & & 6.4 \\
\hline & Aug. & 2.0 & 0.7 & 39.7 \\
\hline & Sep. & 9.2 & 4.6 & 11.1 \\
\hline & Oct. & 6.8 & 2.8 & 30.2 \\
\hline & Nov. & & & * \\
\hline & Dec. & & & $25.0^{*}$ \\
\hline \multirow{12}{*}{1985} & Jan. & & & \\
\hline & Feb. & & & \\
\hline & Mar. & & & \\
\hline & Apr. & & & \\
\hline & May & & & * \\
\hline & Jun. & 21.4 & 14.3 & * \\
\hline & Jul. & 11.8 & 4.4 & 32.8 \\
\hline & Aug. & 9.4 & 2.7 & 54.1 \\
\hline & Sep. & 14.6 & 6.8 & 14.5 \\
\hline & Oct. & 7.0 & 2.0 & 52.7 \\
\hline & Nov. & & & * \\
\hline & Dec. & & & \\
\hline
\end{tabular}

effects on developmental times than changes at lower levels; a decrease in temperature from $20^{\circ}$ to $15^{\circ} \mathrm{C}$ leads to a prolongation of the embryonic development of only 2.2 days; however, following a decrease in temperature from $5^{\circ}$ to $0^{\circ} \mathrm{C}$ the prolongation amounts to 13.1 days (Fig. 10).

Temperature dependence of the duration of intermoult phase and moult increment

Individuals kept at $0^{\circ} \mathrm{C}$ generally accomplish normal moultings, while those maintained at $20^{\circ} \mathrm{C}$ moult once at the best, and die shortly afterwards; many of them die even before moulting is completed. The duration of the intermoult phase shows a distinct dependence on temperature level as well as on body length (Fig. 11; Table 6). The correlation coefficient $r$ reflects individual variations in moulting frequency; the variation of the values around the regression line is due to feeding conditions, food exploitation, developmental stage and maturity of the animals.

The moulting intervals of adult $q \%$ at all temperatures tolerated are associated with a normal development of embryos and larval stages, respectively. This means that also the sum of the periods of embryonic and postembryonic development in the marsupium is still considerably shorter than the intermoult phase of the $q ?$ (Table 6). 


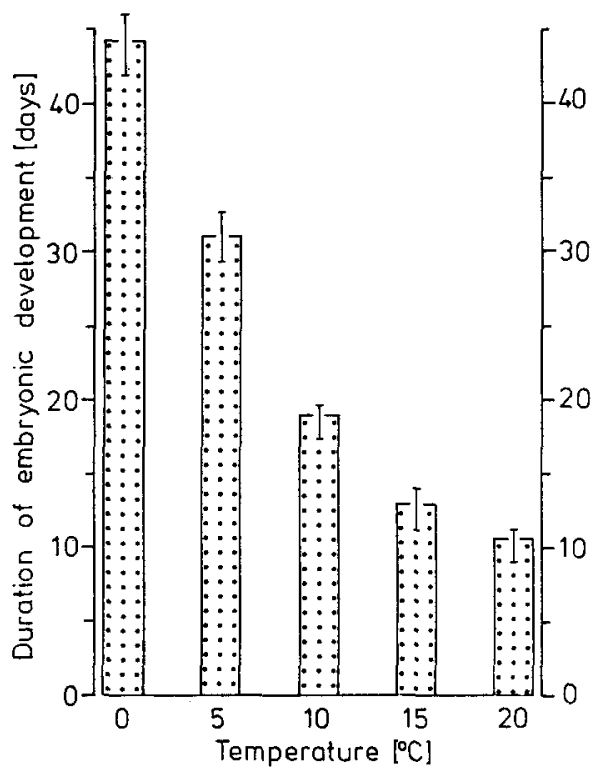

Fig. 10. Hyperia galba. Effects of temperature on duration of embryonic development (mean values \pm standard deviations)

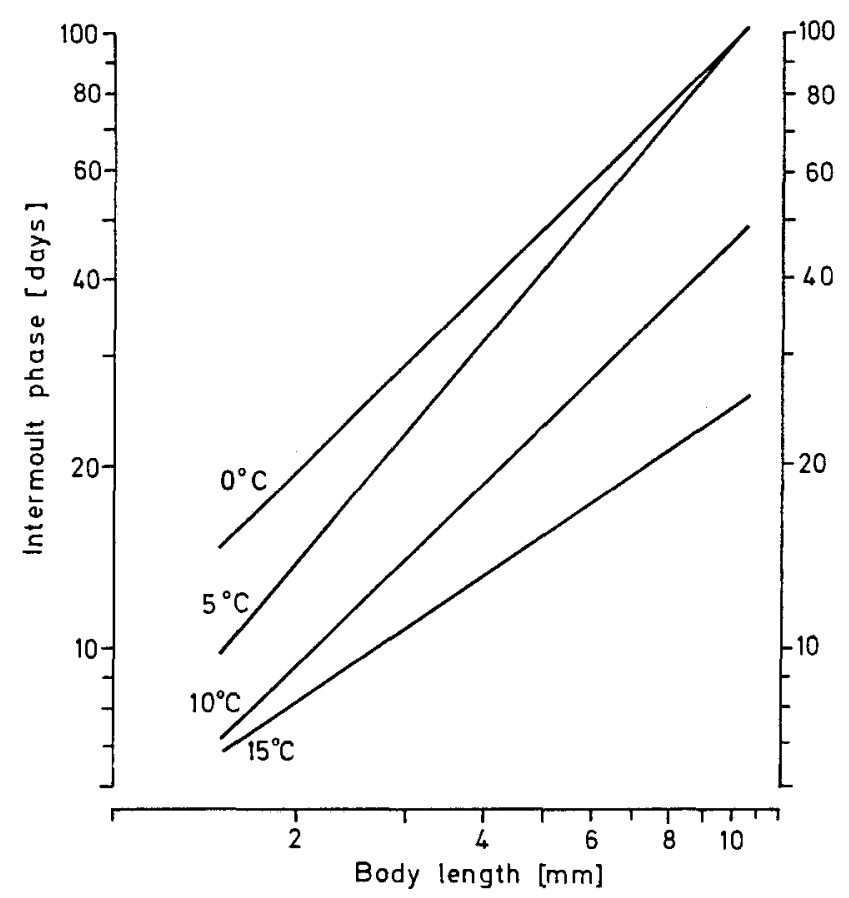

Fig. 11. Hyperia galba. Duration of intermoult phase in relation to temperature and body length 
Table 6. Effects of temperature on the duration of intermoult phase in adult Hyperia galba- $\$ 9$ and on embryonic development of the progeny. Correlation coefficients $(r)$ and regression constants (a and $b$ ) for the regression lines $\left(y=a x^{b}\right)$ given in Fig. 11. F: relation between duration of intermoult phase and embryonic development

\begin{tabular}{|ccccccccc|}
\hline $\begin{array}{c}\text { Temper- } \\
\text { ature } \\
\left({ }^{\circ} \mathrm{C}\right)\end{array}$ & $\begin{array}{c}\text { Duration of } \\
\text { intermoult } \\
\text { (days) }\end{array}$ & a & b & $\mathbf{r}$ & $\mathbf{n}$ & $\begin{array}{c}\text { Duration of } \\
\text { embryonic devel- } \\
\text { opment (days) }\end{array}$ & $\mathrm{n}$ & $\mathbf{F}$ \\
\hline 0 & 64.6 & 2.27 & 0.97 & 0.88 & 15 & $44.3 \pm 1.9$ & 5 & 1.5 \\
5 & 60.2 & 1.80 & 1.18 & 0.87 & 70 & $31.2 \pm 1.2$ & 21 & 1.9 \\
10 & 31.5 & 1.57 & 0.96 & 0.65 & 49 & $19.0 \pm 1.6$ & 60 & 1.7 \\
15 & 19.1 & 1.64 & 0.68 & 0.54 & 107 & $12.5 \pm 1.6$ & 56 & 1.5 \\
\hline
\end{tabular}

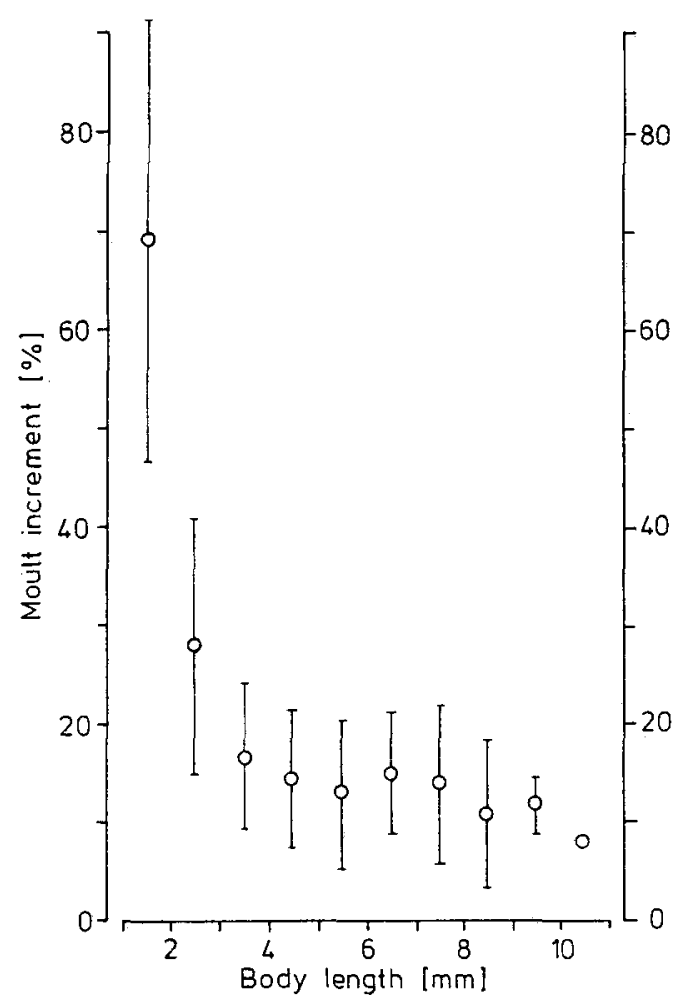

Fig. 12. Hyperia galba. Moult increment related to pre-moult length. (Mean values at different temperatures \pm standard deviation)

The relatively high growth rates in the young up to $3 \mathrm{~mm}$ body length (Fig. 12) are mainly due to positive allometric growth of the abdomen which is still in an embryonic stage at the time of hatching. At a body length of $3 \mathrm{~mm}$, growth rate decreases slightly to finally $5-10 \%$ of premoult length in the adults. 


\section{DISCUSSION}

Due to its intimate association with medusae, Hyperia galba occupies an ecological niche which - at least in European seas - is occupied by no other species. During the course of the investigations in the German Bight, only two further hyperiid species apart from H. galba were found: Parathemisto gaudichaudii and Hyperoche medusarum. However, these species did not occur on medusae, so that interspecific competition for this host does not occur.

Unlike many gammarid species which occur in relatively large densities all the year round, $H$. galba populations are characterized by a distinct seasonal development of the population. While in winter and spring mainly single individuals can be found in the plankton, in summer and autumn these crustaceans often infest the scyphomedusae heavily.

H. galba - subjected not only to seasonally fluctuating temperatures, but also to varying food supply - reveals distinct reproductive periods and specific ecophysiological adaptations (Dittrich, 1986). The rapid increase of the Hyperia population is favoured by the fact that during the reproductive period at least one of the various scyphozoan species is present exhibiting mature gonads. The growth phase of the medusae is completed when planulae are produced (Fig. 2). The following reduction of their gonads and gastric filaments occurs simultaneously with the heavy infestation by $H$. galba. Slight damage by only a few hyperians - especially in the gonads - can be compensated for by the capacity for regeneration in scyphozoans. The rapidly increasing individual infestation and shrinkage of the gonads due to feeding of the hyperiids causes the parasites to consume more and more mesogloea which, however, is regenerated to a much less extent than the gonads. Therefore, as the season advances, increasingly smaller medusae showing more and more morphological reductions can be observed. Following the degeneration of the gonads and gastric filaments, the mesogloea of the umbrella also decays. Finally, almost structureless mesogloea spheres remain, of about a third of the initial size and infested by mainly juvenile hyperians. From the initial phase of degeneration onwards, the medusae can hardly take up further food; therefore, there are scarcely nutrients available for regeneration. The shrunken medusae are no longer capable of directed movements. From the end of October on, most of the individuals have perished and the medusae are basically no longer important as predators of zooplankton in the waters around Helgoland. Heavy infestation by $H$. galba must affect the reproductive rate of the host species; however, no quantitative investigations on the pathogenic potential of $H$. galba have been carried out so far.

The intimate host-parasite interaction becomes obvious particularly during the reproductive phase. The hosts of the Hyperia-larvae found around Helgoland are scyphomedusae of the species Aurelia aurita, Rhizostoma pulmo, Chrysaora hysoscella, Cyanea capillata and Cyanea lamarckii. The first larvae of Hyperia are found when the gonads of the medusae mature, providing optimal feeding conditions. A minimum body size of the hosts is necessary to guarantee the completion of the larval development of Hyperia (Dittrich, 1986); generally, hydromedusae such as Sarsia sp. and Phialidium sp. are too small to permit even a single hyperian a complete larval development. In such a case the larva does not attain the first juvenile stage which is able to swim; only then is a juvenile capable of searching for a new host (Dittrich, 1987). The postembryonic develop- 
ment of Hyperia accounts for the fact that the smallest freely-swimming individuals had a body length of as much as $2.6 \mathrm{~mm}$.

After completion of larval development, coupling spines on the pleopods allow coordinated beating of the pleopods. Then the larvae may leave the medusa, on which the $q$ has released them, and search for a new host. This seems to occur - at least during the daytime - relatively rarely; the percentage of Hyperia found in the plankton independent of medusae was just $0.2 \%$ of the total yield. Of the 44 individuals caught in the plankton during the daytime, 19 were $\delta \delta$ and $18 \% q$ including $1 \% \mathrm{ov}$. In the night, the percentage of $\delta \delta$ in the plankton should be much greater because, in contrast to $\$+$, they are equipped with more differentiated sensory and locomotory structures and actively seek for the $\$ 9$ (Bowman, 1973; Schriever, 1975). Up to now, investigations on how Hyperia finds its host are still lacking.

According to laboratory investigations, these hyperians reach a total body length of $9 \mathrm{~mm}$ after about 9 months at a temperature of $15^{\circ} \mathrm{C}$. The population dynamics suggest that the immense increase during the summer months is due only to the relatively high growth rate, allowing the young hatched in July / August to attain sexual maturity in the autumn of the same year. Possibly a $q$ can produce several broods in rapid succession during one reproductive period. However, this has not yet been observed under laboratory conditions, and data of the moulting frequencies of adult $q q$ in summer are not yet available. According to von Westernhagen (1976), Hyperoche medusarum becomes sexually mature after 69 days at $10^{\circ} \mathrm{C}$; Parathemisto gaudichaudi needs 42 days at $12.5^{\circ} \mathrm{C}$ and $120-180$ days at $5-6^{\circ} \mathrm{C}$ (Sheader, 1981 ; Williams \& Robins, 1981). The fact that Hyperia is closely related to the occurrence of scyphomedusae gives rise to the question of whether there exist two generations differing considerably in their growth rates: a rapidly growing one in summer and a slower growing one during winter-time. The latter may hibernate as relatively small individuals on the benthos, growing rapidly with rising temperature in spring, and producing the first young in early summer.

Concerning the hibernation of $H$. galba, Metz (1967) assumed that it survives the winter in Danish waters on overwintering medusae; however, there is no knowledge so far of hibernating medusae around Helgoland. Buchholz (1953) supposed that $H$. galba hibernates in the Kiel Bight on hydromedusae of the species Melicertum octocostatum, Sarsia tubulosa, Halitholus cirratus, and possibly also on the ctenophores Pleurobrachia pileus and Beroë ovata. However, this was doubted by Thiel (1976) because Kändler (1950, 1961) did not mention these species among the hibernating ones. According to Broch (1928) and Kändler (1961), most of the hydromedusae species are found up to late autumn only and then again in early spring. Those species that also occur in winter Rathkea octopunctata, Euphysia aurata and Obelia sp. (Kändler, 1961) - do not appear to be relevant for the hibernation of $H$. galba because of their small size and their low abundances. Laboratory experiments have indicated that the ctenophore Pleurobrachia pileus loses its swimming ability, sinking to the bottom of the aquarium as soon as it is infested with just one Hyperia-individual (Dittrich, 1986). According to Thiel (1970, 1976), H. galba hibernates on the scyphopolyps of Aurelia aurita. This assumption is supported by my own laboratory observations on choice of food and host organisms: predominantly small individuals hibernate; due to the low water temperatures during winter-time they grow very slowly and remain as small as ca $3 \mathrm{~mm}$. Possibly, falling water 
temperatures (Fig. 1a) and decreasing food supply cause a delay in development, whereby the individuals stay in a subadult stage. Increase in size and maturation of the gonads, being energy-requiring processes, occur in spring and summer together with rising temperatures and increasing diversity of the zooplankton. These suppositions correspond with the results of experiments concerning moulting frequency. Suboptimal nutrition in winter - tested in starved animals under laboratory conditions - also effects a prolongation of the intermoult phase or a complete failure of moulting.

In October - shortly before the medusae population breaks down - the percentage of Hyperia-juveniles increases again while the percentage of sexually mature $\delta \delta$ and $q 9$ decreases; reproduction at this time would make no sense and would be a waste of energy if these young individuals did not hibernate. The monthly size spectra (Fig. 3) exclude hibernation of adult animals; during winter, only individuals of less than $6 \mathrm{~mm}$ in body length occur. From the dry weights of the hyperians found in the Kiel Bight from November to February (Möller, 1978/79), a medium body length of 3-4 mm can be deduced. When they first occur in early summer, smaller individuals are represented by a high percentage (Table 5); at this point in time reproduction does not take place. Rising temperatures and increasing availability of energy-rich food (i. e. maturing gonads of medusae) accelerate growth of hyperians after hibernation, leading to sexual maturity within a short time. This is in accordance with the infestation rate of the scyphozoans (Figs 4,5 ).

The egg number of Hyperia- $q q$ is unusually large; even though it does not attain the same extent as met with in some epicarid isopods, it is, however, several times larger than that observed in other benthic or epibenthic amphipods (Cheng, 1942; Kinne, 1960; Evans, 1968; Sheader \& Chia, 1970; Steele \& Steele, 1975; von Westernhagen, 1976; Sheader, 1977; Anger, 1979). The brood size comprising about 600 eggs as found by White \& Bone (1972) in the Antarctic (South Orkney Islands) is suggested to be due to the much larger body size of the $q$ ov $(22-24 \mathrm{~mm})$ compared with those 9 ov $(7-14 \mathrm{~mm})$ found around Helgoland.

In Lycaea pulex, a hyperiid living on salps, up to 228 eggs per marsupium are reported (Harbison, 1976); this corresponds to the egg number of $H$. galba of the same body length. Contrasting with this observation, the freely-swimming predatory hyperiid Hyperoche medusarum bears only 50-90 eggs per brood (von Westernhagen, 1976). Parathemisto gracilipes, another predatory species, produces only 7-11 eggs per brood (Evans, 1968); however, the young of this species leave the marsupium in a developmental stage that very much resembles the adult.

Among marine malacostracans, the egg number is linearly proportional to the volume of the female (Jensen, 1958). According to Sheader (1977), the egg number of Parathemisto gaudichaudi is proportional to the square of the length of the female. For some Gammarus-species of the western Baltic, regression coefficients between 2.73 and 3.63 were found (Anger, 1979); this corresponds to the values obtained in $H$. galba.

The large brood size effects a reduction of the risks females are exposed to when searching for a host for their progeny. Even though many $q q$ then might become prey to predators, the chance of survival for a certain part of the progeny becomes larger if the $q q$ are attached to several medusae. Changes of hosts may also occur in $\delta \delta$, which are morphologically better adapted to swimming than the $q q$ and therefore may leave their host from time to time to copulate with females on other medusae. Although the mortality 
rate of the $\delta \delta$ might therefore be as high as in $q \%$, this behaviour must result in a higher diversity of the genetic make up.

Data on the duration of embryonic development of hyperiids are scarce. From the release of eggs until hatching of the young, only $8-10$ days at $15^{\circ} \mathrm{C}$ are required in the predator Hyperoche medusarum (von Westernhagen, 1976); thus, the embryonic development proceeds somewhat faster than in Hyperia galba. At temperatures between 10 and $20^{\circ} \mathrm{C}$, the duration of embryonic development in many gammarids, e. $\mathrm{g}$. Gammarus lawrencianus (Steele \& Steele, 1973), G. salinus (Kinne, 1960) and G.duebeni (Kinne, 1953), is comparable to that of $H$. galba; however, with decreasing temperatures, their development times are much longer. Compared with these species, the development of Hyperia at $0^{\circ}-5^{\circ} \mathrm{C}$ is accomplished twice as fast.

In contrast to many evolutionary older parasites among copepods and decapods (Patton, 1967; Vader, 1970; Ross, 1983), H. galba does not show a distinct host specificity. Generally, amphipods associated with other invertebrates do not show distinct adaptations such as those known of certain cirripedes or isopods. According to the results made available, Hyperia has not undergone a development towards becoming a food specialist: in the arctic-boreal seas of its distribution, medusae occur only in summer; additionally, the diversity of planktonic food species changes seasonally so that a food specialist would have no chance of survival.

The group of organisms accepted as food is as diverse as the group of predators (Fig. 13). In arctic-boreal seas, hyperiids often occur in dense swarms and serve as food

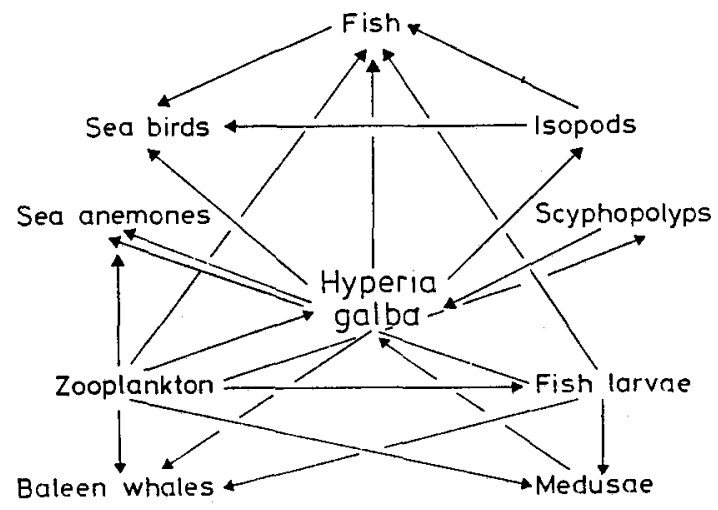

Fig. 13. Role of Hyperia galba within the marine food web

for e. g. baleen whales (Lowry \& Frost, 1984 ; Nemoto \& Yoo, 1970). Some species of sea birds and many species of fish feed on these crustaceans (Fenwick, 1978). Many sea birds feed exclusively on hyperiids and ". . . were observed to perforate the Aurelia and eat the Hyperia" (Rasmussen, 1973) when swept on the shore. Anger (1975) found the isopod Idotea baltica attacking freely-swimming hyperians during the night. Young fish associated with medusae do not apparently represent a threat for the hyperians. In contrast to Hyperoche medusarum (von Westernhagen, 1976), Hyperia galba does not play any role as predator on fish larvae, and in dire ctly has a positive effect on the standing stock 
of fish: incidence and intensity of infestation by $H$. galba play a significant role in the performance of the scyphomedusae which may act as predators of fish (Kerstan, 1977; van der Veer \& Oorthuysen, 1985) and, finally, the amphipods contribute to the breakdown of the jellyfish population.

Acknowledgements. This paper was completed while the author's work was supported by the Studienstiftung des Deutschen Volkes. My sincere thanks are due to Prof. Dr. H. Mergner for supervising the investigations, and to Prof. Dr. H.-P. Bulnheim for providing laboratory space at the Biologische Anstalt Helgoland, and for his suggestions and constructive criticism. I wish to thank Mr. P. Mangelsdorf and Mr. K. Treutner for providing the hydrographical data. Thanks are also due to Dr. M. Rieper for her critical reading of the English manuscript.

\section{LITERATURE CITED}

Anger, K., 1975. Benthos und Abwasser. Die Auswirkung kommunaler Abwässer auf ein ufernahes Partialökosystem der westlichen Ostsee. Diss., Christian-Albrechts-Univ. Kiel, 327 pp.

Anger, K., 1979. Die Beziehung zwischen Körpergröße, Trockengewicht und Eizahl bei einigen Amphipoden der westlichen Ostsee. - Mitt. zool. Mus. Univ. Kiel, 1 (3), 7-11.

Bowman, T. E., 1973. Pelagic amphipods of the genus Hyperia and closely related genera (Hyperiidea: Hyperiidae). - Smithson. Contr. Zool. 136, 1-76.

Broch, H., 1928. Hydrozoa I.-Tierw. Nord- u. Ostsee 3b, 1-100.

Buchholz, H. A., 1953. Die Wirtstiere des Amphipoden Hyperia galba in der Kieler Bucht. - Faun. Mitt. Norddeutschland 3, 5-6.

Cheng, C., 1942. On the fecundity of some gammarids. - J. mar. biol. Ass. U. K. 25, 465-475.

Dittrich, B., 1986. Beiträge zur Biologie und Ökologie von Hyperia galba (Montagu, 1813). Diss. Univ. Bochum, 202 pp.

Dittrich, B., 1987. Postembryonic development of the parasitic amphipod Hyperia galba. - Helgoländer Meersunters. 41, 217-232.

Edward, T., 1866. Stray notes on some of the smaller crustaceans. Note II. On the habits of the Hyperiidae. - J. Linn. Soc. (Zool.) 9 (48), 166-170.

Evans, F., 1968. Development and reproduction of Parathemisto gracilipes (Norman) (Amphipoda, Hyperiidea) in the North Sea. - Crustaceana 15, 101-109.

Fenwick, G. D., 1978. Plankton swarms and their predators at the Snares Islands. - N. Z. Jl mar. Freshwat. Res. 12, 223-229.

Gould, A. A., 1841. Report on the invertebrates of Massachusetts. Zoological and Botanical Survey of Massachusetts. Commissioners for the Zoological and Botanical Survey of the State, Cambridge, U.S. A.

Harbison, G. R., 1976. Development of Lycaea pulex Marion, 1874 and Lycaea vincentii Stebbing, 1888. - Bull. mar. Sci. 26, 152-164.

Harbison, G. R., Biggs, D. C. \& Madin, L. P., 1977. The associations of Amphipoda Hyperiidea with gelatinous zooplankton. - I. Associations with Cnidaria, Ctenophora and Radiolaria. - Deep-Sea Res. $24,465-488$.

Hollowday, E. D., 1947. On the commensal relationship between the amphipod Hyperia galba (Mont.) and the scyphomedusa Rhizostoma pulmo Agassiz, var. octopus Oken. - J. Quekett microsc. Club (Ser. 4) 2 (4), 187-180.

Jensen, J. P., 1958. The relation between body size and number of eggs in marine malacostracs. Meddr Danm. Fisk. - og Havunders. (N. S.) 2 (19), 1-25.

Kändler, R., 1950. Jahreszeitliches Vorkommen und unperiodisches Auftreten von Fischbrut, Medusen und Decapodenlarven im Fehmarnbelt in den Jahren 1934-43. - Ber. dt. wiss. Kommn Meeresforsch. 12, 49-85.

Kändler, R., 1961. Über das Vorkommen von Fischbrut, Decapodenlarven und Medusen in der Kieler Förde. - Kieler Meeresforsch. 17, 48-64.

Kerstan, M., 1977. Untersuchungen zur Nahrungsökologie von Aurelia aurita. Dipl.-Arb., Univ. Kiel, $95 \mathrm{pp}$. 
Kinne, O., 1953. Zur Biologie und Physiologie von Gammarus duebeni Lillj., VI. Produktionsbiologische Studie. - Veröff. Inst. Meeresforsch. Bremerhaven 2, 135-145.

Kinne, O., 1960. Growth, molting frequency, heart beat, number of eggs and incubation time in Gammarus zaddachi exposed to different environments. - Crustaceana 2, 26-36.

Lauckner, G., 1980. Diseases of Cnidaria. In: Diseases of marine animals. Ed. by O. Kinne. Wiley, Chichester, 1, 167-237.

Lowry, L. F. \& Frost, K. J., 1984. Foods and feeding of bowhead whales in western and northern Alaska. - Scient. Rep. Whales Res. Inst. 35, 1-16.

Metz, P., 1967. On the relations between Hyperia galba Montagu (Amphipoda, Hyperiidae) and its host Aurelia aurita in the Isefjord Area (Sjaelland, Denmark). - Vidensk. Meddr dansk. naturh. Foren. 130, 85-108.

Möller, H., 1978/79. Significance of coelenterates in relation to other plankton organisms. Meeresforsch. 27, 1-18.

Nemoto, T. \& Yoo, K. I., 1970. An amphipod, (Parathemisto gaudichandii) as a food of the Antarctic sei whale. - Scient. Rep. Whales Res. Inst. 22, 153-158.

Patton, W. K., 1967. Commensal crustacea. - Proc. Symp. Crustacea mar. biol. Ass. India 3, 1228-1243.

Rasmussen, E., 1973. Systematics and ecology of the Isefjord. - Ophelia 11, 1-495.

Ross, D. M., 1983. Symbiotic relationships. In: The biology of Crustacea. Ed. by D. Bliss. Acad. Press, New York, 7, 163-213.

Schriever, G., 1975. In situ-Beobachtungen an Hyperia galba Montagu (Amphipoda, Hyperiidea) in der westlichen Ostsee. - Kieler Meeresforsch. 31, 107-110.

Sheader, M., 1977. Breeding and marsupial development in laboratory-maintained Parathemisto gaudichaudi. - J. mar. biol. Ass. U. K. 57, 943-954.

Sheader, M., 1981. Development and growth in laboratory-maintained and field populations of Parathemisto gaudichaudi (Hyperiidea: Amphipoda). - J. mar. biol. Ass. U. K. 61, 769-787.

Sheader, M. \& Chia, F., 1970. Development, fecundity and brooding behaviour of the amphipod, Marinogammarus obtusatus. - J. mar. biol. Ass. U. K. 50, 1079-1099.

Sokolowsky, A., 1900. Die Amphipoden Helgolands. - Wiss. Meeresunters. (Abt. Helgoland) 4, 143-166.

Steele, D. H. \& Steele, V. J., 1973. The biology of Gammarus (Crustacea, Amphipoda) in the northwestern Atlantic. VII. The duration of embryonic development in five species at various temperatures. - Can. J. Zool. 51, 995-999.

Steele, D. H. \& Steele, V. J., 1975. The biology of Gammarus (Crustacea, Amphipoda) in the northwestern Atlantic. XI. Comparison and discussion. - Can. J. Zool. 53, 1116-1126.

Thiel, H., 1970. Beobachtungen an den Hydroiden der Kieler Bucht. - Ber. dt. wiss. Kommn Meeresforsch. 21, 474-493.

Thiel, M. E., 1976. Wirbellose Meerestiere als Parasiten, Kommensalen oder Symbionten in oder an Scyphomedusen. - Helgoländer wiss. Meeresunters. 28, 417-446.

Vader, W., 1970. Antheacheres duebeni M. Sars, a copepod parasitic in the sea anemone, Bolocera tuediae (Johnston), - Sarsia 43, 99-106.

Veer, H. W. van der \& Oorthuysen, W., 1985. Abundance, growth and food demand of the scyphomedusa Aurelia aurita in the western Wadden Sea. - Neth. J. Sea. Res. 19, 38-44.

Westernhagen, H. von, 1976. Some aspects of the biology of the hyperiid amphipod Hyperoche medusarum. - Helgoländer wiss. Meeresunters. 28, 43-50.

White, M. G. \& Bone, D. G., 1972. The interrelationship of Hyperia galba (Crustacea, Amphipoda) and Desmonema gaudichaudi (Scyphomedusae, Semaeostomae) from the Antarctic. - Br. Antarct. Surv. Bull. 27, 39-49.

Williams, R. \& Robins, D., 1981. Seasonal variability in abundance and vertical distribution of Parathemisto gaudichaudi (Amphipoda: Hyperiidea) in the north east Atlantic Ocean. - Mar. Ecol. Prog. Ser. 4, 289-298. 